\title{
Exhaust Gas Analysis of CI Engine using the Blends of Diesel and Biodiesel from the seed of Pongamia pinnata (L) Pierre
}

\author{
Brahma Dr. Kamal Kr. \\ Associate Professor, Mechanical Engineering Department \\ Assam Engineering College, Guwahati, India \\ Mahanta Dr. Dimbendra Kumar \\ Professor, Mechanical Engineering Department \\ Assam Engineering College, Guwahati, India
}

\begin{abstract}
:
Exhaust system plays most effective role on the environment as it is that portion of an automobile through which exhaust gases get out from the combustion chamber to pollute the air by their harmful gases. The different blends of diesel and biodiesel from the Pongamia ponnata $(L)$ Pierre are used to run the four stroke compression ignition engine. To make a study of the exhaust gas emission providing with blends of diesel and biodiesel at different ratio and exhaust gas analyzer was used to collect experimental data. All the experimental data and graphical representation concludes that the $\mathrm{CO}, \mathrm{CO}_{2}, \mathrm{HC}, \mathrm{NO}, \mathrm{NO}_{2}, \mathrm{NO}_{X}, \mathrm{SO}_{X}$ in the exhaust gas from $\mathrm{CI}$ engine with the use of blending of diesel and biodiesel.
\end{abstract}

Keywords: Exhaust gas, CI engine, Blending, diesel, biodiesel.

\section{Introduction}

Exhaust emissions are produced during combustion and the emissions are harmful. In addition to these harmful emissions, both carbon dioxide $\left(\mathrm{CO}_{2}\right)$ and oxygen $\left(\mathrm{O}_{2}\right)$ readings can provide additional information on what's going on inside the combustion chamber.

Carbon dioxide $\left(\mathrm{CO}_{2}\right)$ is a desirable by-product that is produced when the carbon from the fuel is fully oxidized during the combustion process. As a general rule, the higher the carbon dioxide reading, the more efficient the engine is operating. Therefore air/fuel imbalances, misfires or mechanical problems will causes $\mathrm{CO}_{2}$ to decrease. It is noted that "ideal" combustion produces large amount of $\mathrm{CO}_{2}$ and $\mathrm{H}_{2} \mathrm{O}$ (water vapour)

Oxygen $\left(\mathrm{O}_{2}\right)$ readings provide a good indication of a lean running engine, since $\mathrm{O}_{2}$ increase with leaner air/fuel mixtures. Lean air/fuel mixtures and misfires typically cause high $\mathrm{O}_{2}$ output from the engine.

There are a few other exhaust emission components which impact driveability and/or emissions diagnosis, that are not measured by shop analysers. They are (a) water vapour $\left(\mathrm{H}_{2} \mathrm{O}\right)$, (b) sulphur dioxide $\left(\mathrm{SO}_{2}\right)$, (c) hydrogen $(\mathrm{H})$ and $(\mathrm{d})$ particulate carbon soot $(\mathrm{C})$. 
Sulphur dioxide $\left(\mathrm{SO}_{2}\right)$ is sometimes created during the combustion process from the small amount of sulphur present in the gasoline. During certain conditions the catalyst oxidizes sulphur dioxide to make $\mathrm{SO}_{3}$, which then reacts with water to make $\mathrm{H}_{2} \mathrm{SO}_{4}$ or sulphuric acid. Finally, when sulphur and hydrogen react, it forms hydrogen sulphide gas. This process creates the rotten egg odour we sometimes smell when following vehicles in the highway. Particulate carbon soot is the visible black smoke we see from the tailpipe of a vehicle that's running very rich.

The quantity of $\mathrm{NO}_{\mathrm{x}}$ varies from a few hundred to well over $1000 \mathrm{ppm}$ in diesel exhaust. Oxides of nitrogen which also occur only in the engine exhaust are combination of nitric oxide (NO) and nitrogen dioxide $\left(\mathrm{NO}_{2}\right)$. Nitrogen and oxygen reacts at relatively high temperatures. Therefore high temperature and availability of oxygen are the two main reasons for the formation of $\mathrm{NO}_{\mathrm{x}}$. When the proper amount of the oxygen is available the higher the peak combustion temperature the more is the NO formed. The $\mathrm{NO}_{\mathrm{x}}$ is formed in the atmosphere as NO oxidizes. The combination of $\mathrm{HC}$ and $\mathrm{NO}_{\mathrm{x}}$ in the presence of sunlight and certain atmospheric condition produce photochemical smog. The conditions that cause highest local peak temperature and have sufficient oxygen give highest $\mathrm{NO}_{\mathrm{x}}$ concentration in diesel exhaust.

A pre-combustion chamber engine produces less $\mathrm{NO}_{\mathrm{x}}$ than a direct injection engine due to lower peak temperature. The effect of fuel-air ratio is same that on a gasoline engine. At high fuel-air ratio the additional fuel tends to cool the charge, so the localized peak temperatures are lowered resulting in drop in $\mathrm{NO}_{\mathrm{x}}$ concentration. The $\mathrm{NO}_{\mathrm{x}}$ production is also significantly affected by injection system and time. Also, variations in fuel characteristics such as cetane number, viscosity, modulus of elasticity and rate of burning, etc., all contribute to differences in $\mathrm{NO}_{\mathrm{x}}$ levels obtained from different levels.

\section{Literature Review}

Some papers in connection with the exhaust gas analysis were studied and brief definitions related to the exhaust gas analysis were given below:

Leung DYC et al considered a single cylinder diesel engine, direct injection, water cooled engine for optimization of exhaust emission with biodiesel ${ }^{(\mathbf{1})}$. They optimized by varying the engine settings, including the injection timing, injection pressure and the fuel pump plunger diameter. The engine emissions were found to be lowered for particulate matters (PM) and hydrocarbon (HC) with the use of biodiesel, but an obvious increase in the oxides of nitrogen $\left(\mathrm{NO}_{\mathrm{x}}\right)$ was observed, particularly at high engine loadings. For multi parameter engine, adjustment with the consideration of their cross interactive effects can keep the benefit of reducing $\mathrm{PM}$ and $\mathrm{HC}$ without increasing $\mathrm{NO}_{\mathrm{x}}$ emission and sacrificing fuel combustion efficiency. 
Breda Kegl investigates in his study the optimal timing of the diesel engine injection pump using biodiesel fuel from rapeseed ${ }^{(2)}$. He studied by running experiments on an NA diesel bus engine MAN D2 2566 with direct injection M system for the influence of biodiesel. Experiments with biodiesel and D2 diesel are run on several engine operating regimes and shown that with carefully optimized timing of the pump, the harmful emission of $\mathrm{NO}_{\mathrm{x}}$, smoke, $\mathrm{HC}$ and $\mathrm{CO}$ can be reduced essentially by keeping other engine characteristics within acceptable limits.

Zhang et al investigated the impact of biodiesel on $\mathrm{NO}_{\mathrm{x}}$ emission in a $2.5 \mathrm{~L}$ common rail direct injection diesel engine under both low load and high load conditions with different fuel injections strategies $^{(3)}$. They used three fuels (i) an ultra low sulfur diesel fuel (BP15), (ii) a blend of 20 vol\% biodiesel in BP15 and (iii) a blend of 40 vol\% biodiesel in BP15 (B40). Biodiesel blends were found to generally produce slightly lower $\mathrm{NO}_{\mathrm{x}}$ emissions than the baseline diesel fuel at the low load condition. Under the high load condition, evidently higher $\mathrm{NO}_{\mathrm{x}}$ emissions for biodiesel blends were observed under both single and double injection conditions. Overall, biodiesel blends and the baseline diesel fuel had very similar heat release rate profile. For injection systems, retarding injection timing under single injection conditions was found to be the more effective approach to reduce the $\mathrm{NO}_{\mathrm{x}}$ emissions than using pilot injection with retarded main injection in terms of $\mathrm{NO}_{\mathrm{x}}$ and fuel consumption trade off. The performance of the $40 \mathrm{vol} \%$ biodiesel blend under various exhaust gas recirculation (EGR) rate condition was investigated, the biodiesel blend showed no further combustion deterioration compared to baseline diesel fuel. A low $\mathrm{NO}_{\mathrm{x}}$ and fuel efficient engine operating condition was achieved with the $40 \mathrm{vol} \%$ biodiesel blend.

Cheng C. S. et al in their study aimed to investigate the effects of fumigation methanol on the emission of a diesel engine fueled with biodiesel as the baseline fuel ${ }^{(4)}$. The biodiesel used in this study was converted from waste cooking oil. Experiments were performed on a 4-cylinder naturally aspirated diesel engine operating at a constant speed of $1800 \mathrm{rev} / \mathrm{min}$ for three engine loads of $0.19 \mathrm{MPa}, 0.38 \mathrm{MPa}$ and $0.56 \mathrm{MPa}$. The results indicate no significant change in the brake thermal efficiency and carbon dioxide $\left(\mathrm{CO}_{2}\right)$ emission, an increase in both carbon monoxide $(\mathrm{CO})$ and unburned hydrocarbon $(\mathrm{HC})$ emission and a decrease in both nitrogen oxide $\left(\mathrm{NO}_{\mathrm{x}}\right)$ and particulate matter $(\mathrm{PM})$ emissions.

Their paper presents the results of investigations carried out in studying the fuel properties of karanja methyl ester (KME) and its blend with diesel from $20 \%$ to $80 \%$ by volume and running a diesel engine with these fuels ${ }^{(\mathbf{5})}$. Engine tests have been carried out with the air of obtaining comparative measures of torque, power, specific fuel consumption and emission such as $\mathrm{CO}$, smoke density and $\mathrm{NO}_{\mathrm{x}}$ to evaluate and compute the behavior of diesel engine running on the KME fuel. The reduction in exhaust emissions together with increase in torque, brake power, brake thermal efficiency and reduction in brake-specific fuel consumption made blends of karanja esterified oil (B20 and B40) a suitable alternative for diesel and could help controlling air pollution. 
In their study, a number of experiments with $10 \mathrm{vol} \%$ (B10) biodiesel fuel of palm oil origin were performed on a light duty common-rail Euro 3 engine ${ }^{(\mathbf{6})}$. The measurements included in-cylinder pressure, pollutant emission and fuel consumption. Combustion effects were limited but changes in the start of ignition and heat release rate could be identified. Emission effects included both higher and lower smoke and $\mathrm{NO}_{\mathrm{x}}$, depending on the operation point. The results on the engine bench were compared against a Euro 3 common-rail high-duty vehicle driven on the chassis dynamometer, in order to include the effects of emission control system (EGR \& oxidation catalyst). In addition to the palm biodiesel, an RME-diesel blends was also tested to examine the effect of a fuel with different characteristics. Both biodiesel blends reduced PM emissions and only marginal effects on $\mathrm{NO}_{\mathrm{x}}$ over the certification test could be identified. The results of this study show that up to $10 \%$ biodiesel could be used on current diesel vehicles, without significantly affecting vehicle emission performance.

Blends of diesel oil and soybean biodiesel with concentration of 3\% (B3), 5\% (B5), 10\% (B10) and 20\% (B20) were used as fuel on a passenger vehicle and exhaust pollutant emissions were investigated ${ }^{(7)}$. The effects of anhydrous ethanol as an additive to B20 fuel blend with concentration of 2\% (B20E2) and 5\% (B20E5) were also studied. The emissions tests were carried out following New European Driving Cycle (NEDC). Results shows that increasing biodiesel concentration in the fuel blend increase $\mathrm{CO}_{2}$ and oxides of nitrogen $\left(\mathrm{NO}_{\mathrm{x}}\right)$ emissions, while carbon monoxide (CO), Hydrocarbon ( $\mathrm{HC}$ ) and particulate matter (PM) emissions are reduced. The addition of anhydrous ethanol to B20 fuel blend proved it can be a strategy to control exhaust $\mathrm{NO}_{\mathrm{x}}$ and global warming effects through the reduction of $\mathrm{CO}_{2}$ concentration.

\section{Engine Setup}

Experiments were conducted on an existing test unit. The test unit was a Single Cylinder, Naturally Aspirated, Direct Injection, and Compression Ignition Engine using standard diesel fuel

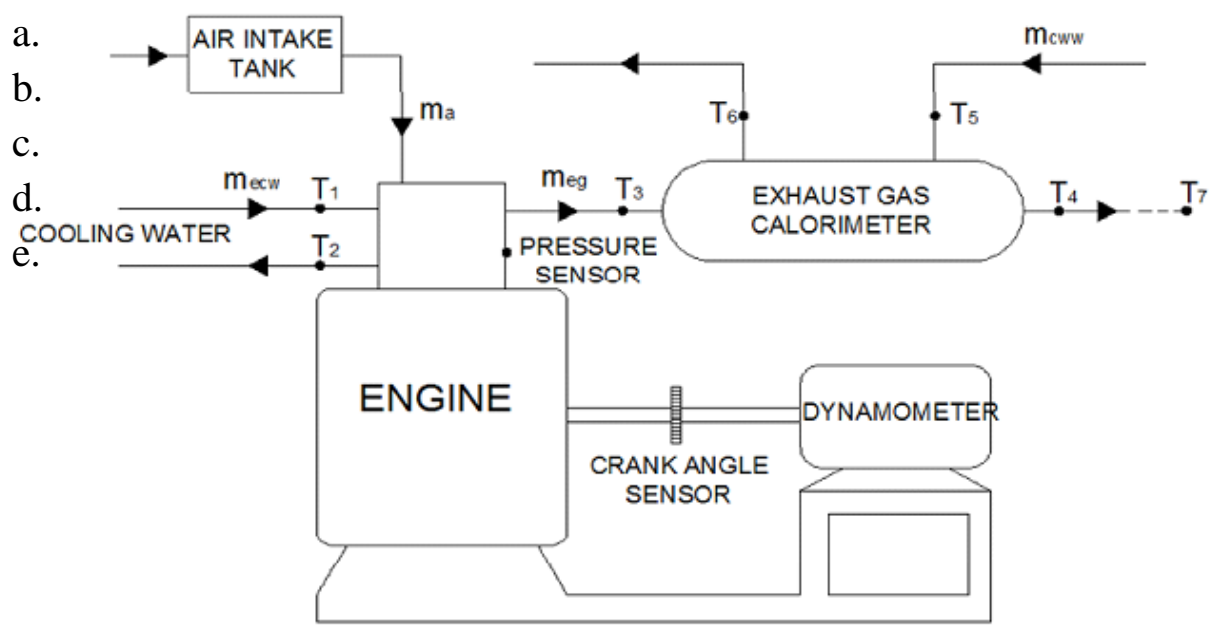

Fig.1: Schematic diagram of engine test unit (Source: www.elsevier.com/locate/pecs) 


\section{Exhaust Gas Analysis}

Exhaust emissions are produced during combustion and the emissions are harmful. In addition to these harmful emissions, both carbon dioxide $\left(\mathrm{CO}_{2}\right)$ and oxygen $\left(\mathrm{O}_{2}\right)$ readings can provide additional information on what's going on inside the combustion chamber.

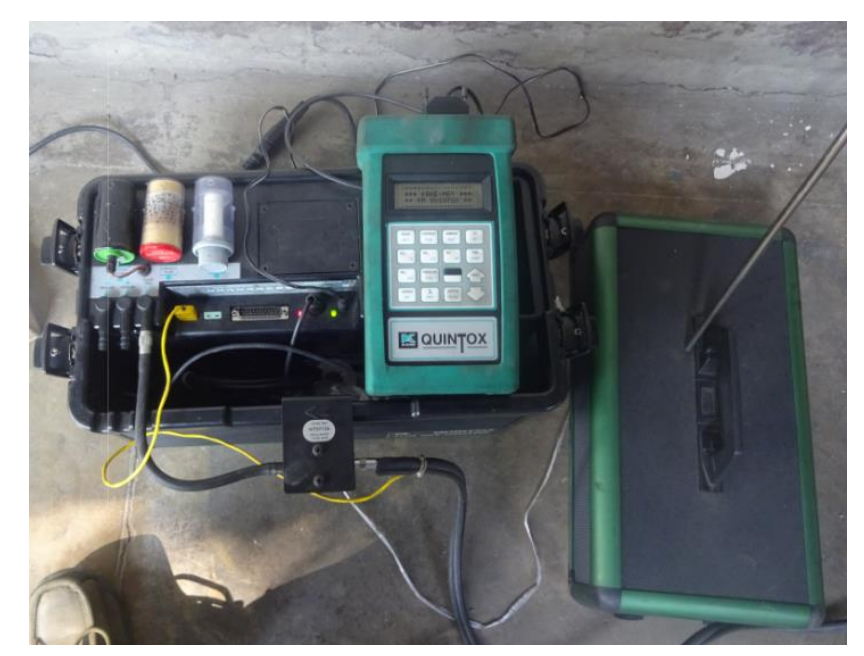

Fig. 2: Exhaust Gas Analyser

\section{Analysing Exhaust Emission Readings}

Hydrocarbons are measured by an exhaust analyser in parts per million (ppm). It is known that $\mathrm{HC}$ is unburned fuel that remains as a result of a misfire. When combustion does not take place or when only part of the air/fuel charge burns, hydrocarbon levels goes up.

Carbon monoxide (CO) is measured by an exhaust analyser in percentage (\%) or parts per hundred. $\mathrm{CO}$ is a by-product of combustion; therefore, if combustion does not take place, carbon monoxide will not be created. Based on this premise, when a misfire occurs, the carbon monoxide that would have normally been produced during the production process is not produce. Generally speaking, on fuel injected vehicles, high CO means too much fuel is being delivered to the engine for the amount of air entering the intake manifold.

Nitrogen oxide measured by an exhaust analyser in parts per million (ppm). Nitrogen oxides are a by-product of combustion. $\mathrm{NO}_{\mathrm{x}}$ is formed in large quantities when combustion temperatures exceed about $1370^{\circ} \mathrm{C}\left(2500^{\circ} \mathrm{F}\right)$. Anything which causes combustion temperatures to rise will also cause $\mathrm{NO}_{\mathrm{x}}$ emissions to rise. Misfire can also cause $\mathrm{NO}_{\mathrm{x}}$ to rise because of the increase in oxygen that it causes in the catalytic converter feed gas.

Carbon Dioxide measured by an exhaust analyser in percentage $(\%)$ or parts per hundred. Carbon dioxide is a by-product of efficient and complete combustion. Near perfect combustion will result in carbon dioxide levels which approach the theoretical maximum of $15.5 \%$. Carbon dioxide levels are affected by air/fuel ratio, spark timing and any other factors which affect the combustion efficiency. 
Oxygen is measured by an exhaust analyser in percentage $(\%)$ or parts per hundred. The amount of oxygen produced by an engine is affected by how close the air/fuel ratio is to stoichiometry. As the mixture goes lean of stoichiometry, oxygen increases. As mixture goes rich of stoichiometry, oxygen falls to zero. Because oxygen is used up in the combustion process, concentrations at the tailpipe will be very low. If misfire occurs, however, oxygen will increase dramatically as it passes unused through the combustion chamber.

\section{General Rules of Emission Analysis}

If $\mathrm{CO}$ goes up, $\mathrm{O}_{2}$ goes down and conversely if $\mathrm{O}_{2}$ goes up, $\mathrm{CO}$ goes down. It is noted that $\mathrm{CO}$ readings are indicator of a rich running engine and $\mathrm{O}_{2}$ readings are an indicator of a lean running engine.

If $\mathrm{HC}$ increases as a result of a lean misfire, $\mathrm{O}_{2}$ will also increases.

$\mathrm{CO}_{2}$ will decrease in any of the above cases because of an air/fuel imbalance or misfire.

An increase in $\mathrm{CO}$ does not necessarily mean there will be an increase in HC. Additional $\mathrm{HC}$ will only be created at the point where rich misfire begins ( $3 \%$ to $4 \% \mathrm{CO})$.

High $\mathrm{HC}$, low $\mathrm{CO}$ and high $\mathrm{O}_{2}$ at same time indicates a misfire due to lean or EGR diluted mixture.

High $\mathrm{HC}$, high $\mathrm{CO}$ and high $\mathrm{O}_{2}$ at same time indicate a misfire due to excessively rich mixture.

High $\mathrm{HC}$, Normal to marginally low $\mathrm{CO}$, High $\mathrm{O}_{2}$, indicates a misfire due to mechanical engine problem or ignition misfire.

Normal to marginally high $\mathrm{HC}$, Normal to marginally low $\mathrm{CO}$ and high $\mathrm{O}_{2}$ indicates a misfire due to false air or marginally lean mixture.

\section{Ambient values of the exhaust parameters are given below:}

$\mathrm{CO}=6 \mathrm{mg} / \mathrm{m}^{3} ; \mathrm{CO}_{2}=0 \% ; \mathrm{HC}=0 \mathrm{ppm} ; \mathrm{NO}=1 \mathrm{mg} / \mathrm{m}^{3} ; \mathrm{NO}_{2}=0 \mathrm{mg} / \mathrm{m}^{3} ; \mathrm{NO}_{\mathrm{x}}=1$ $\mathrm{mg} / \mathrm{m}^{3} ; \mathrm{SO}_{\mathrm{x}}=0 \mathrm{mg} / \mathrm{m}^{3}$ and Ambient temperature $=24^{\circ} \mathrm{C}$

The different values of the exhaust gas elements are shown in the following tables and the respective figures are shown as belows:

Table 1: Particulars of exhaust gas for the samples at different loads.

\begin{tabular}{|c|l|c|c|c|c|c|c|}
\hline Sl. & Particulars & Load & \multicolumn{6}{|c|}{ Samples } \\
\cline { 3 - 8 } No & & $(\mathrm{kg})$ & $B 00$ & $B 10$ & $B 20$ & $B 30$ & $B 100$ \\
\hline & & & & & & & \\
\hline \multirow{3}{*}{1} & $\mathrm{CO}\left(\mathrm{mg} / \mathrm{m}^{3}\right)$ & 5 & 81 & 76 & 61 & 36 & 34 \\
\cline { 3 - 8 } & & 10 & 80 & 76 & 61 & 36 & 34 \\
\cline { 3 - 8 } & & 15 & 79 & 75 & 63 & 38 & 33 \\
\hline \multirow{2}{*}{2} & $\mathrm{CO}_{2}(\%)$ & 5 & 1.2 & 1.1 & 1.1 & 1.2 & 1.2 \\
\cline { 3 - 8 } & & 10 & 1.3 & 1.3 & 1.3 & 1.3 & 1.3 \\
\cline { 3 - 8 } & & 15 & 1.5 & 1.5 & 1.5 & 1.5 & 1.4 \\
\hline 3 & $\mathrm{HC}(\mathrm{ppm})$ & 5 & 25 & 25 & 27 & 28 & 28 \\
\hline
\end{tabular}




\begin{tabular}{|c|c|c|c|c|c|c|c|}
\hline \multirow{2}{*}{4} & 10 & 25 & 25 & 26 & 27 & 27 \\
\cline { 3 - 8 } & \multirow{2}{*}{$\mathrm{NO}\left(\mathrm{mg} / \mathrm{m}^{3}\right)$} & 15 & 25 & 25 & 26 & 26 & 27 \\
\cline { 3 - 8 } & & 5 & 59 & 60 & 60 & 60 & 60 \\
\cline { 3 - 8 } & & 10 & 88 & 97 & 101 & 101 & 101 \\
\hline \multirow{2}{*}{5} & $\mathrm{NO}_{2}\left(\mathrm{mg} / \mathrm{m}^{3}\right)$ & 5 & 43 & 45 & 47 & 49 & 49 \\
\cline { 3 - 8 } & & 10 & 45 & 49 & 57 & 57 & 59 \\
\cline { 3 - 8 } & & 15 & 55 & 56 & 58 & 58 & 60 \\
\hline \multirow{2}{*}{6} & \multirow{2}{*}{$\mathrm{NO}_{\mathrm{x}}\left(\mathrm{mg} / \mathrm{m}^{3}\right)$} & 5 & 106 & 109 & 112 & 115 & 121 \\
\cline { 3 - 8 } & & 10 & 133 & 135 & 142 & 152 & 163 \\
\cline { 3 - 8 } & & 15 & 188 & 219 & 249 & 271 & 288 \\
\hline 7 & $\mathrm{SO}_{\mathrm{x}}\left(\mathrm{mg} / \mathrm{m}^{3}\right)$ & 5 & 3 & - & - & - & - \\
\cline { 3 - 8 } & & 10 & 3 & - & - & - & - \\
\cline { 3 - 8 } & & 15 & 3 & - & - & - & - \\
\hline
\end{tabular}

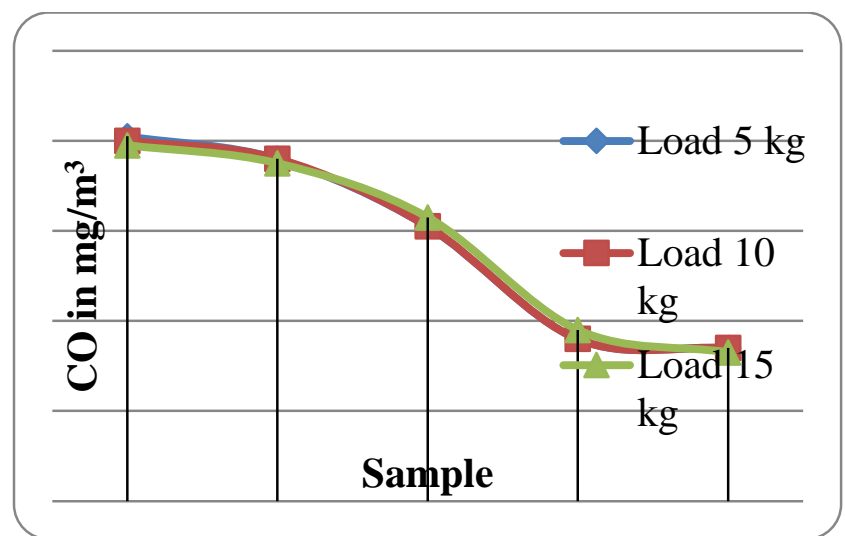

Figure 3: Change of $\mathrm{CO}$ with respect to load for different samples

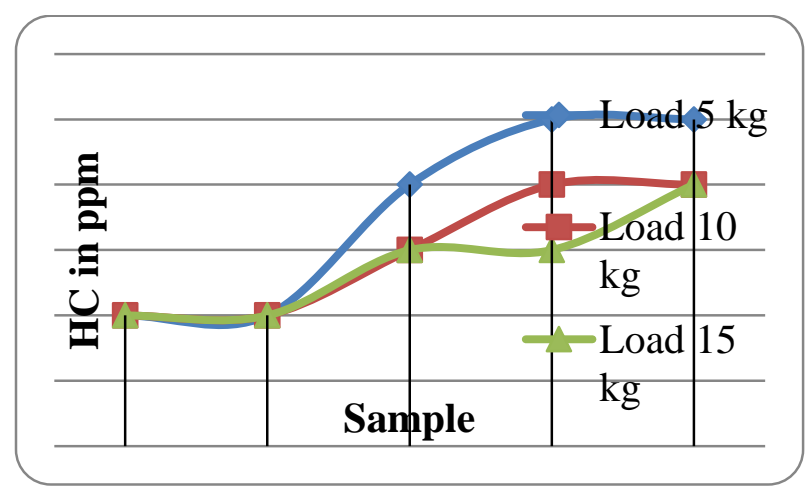

Figure 5: Change of HC with respect to load for different samples

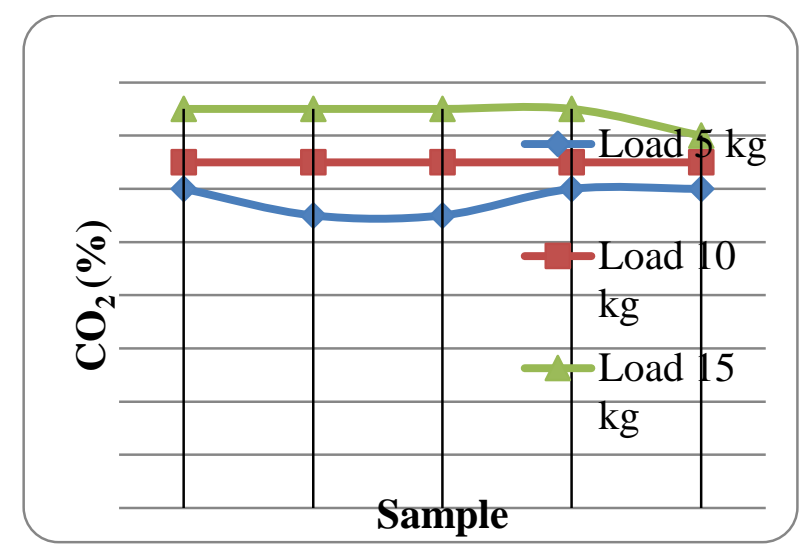

Figure 4: Change of $\mathrm{CO}_{2}$ with respect to load for different samples

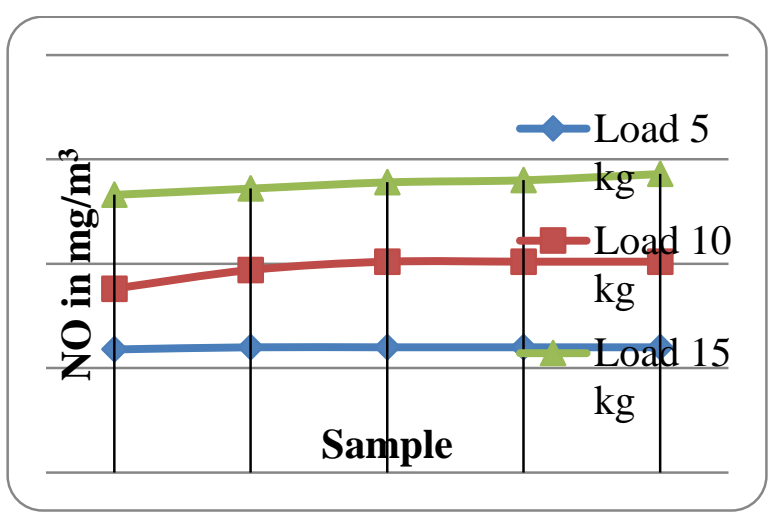

Figure 6: Change of NO with respect to load for different samples 


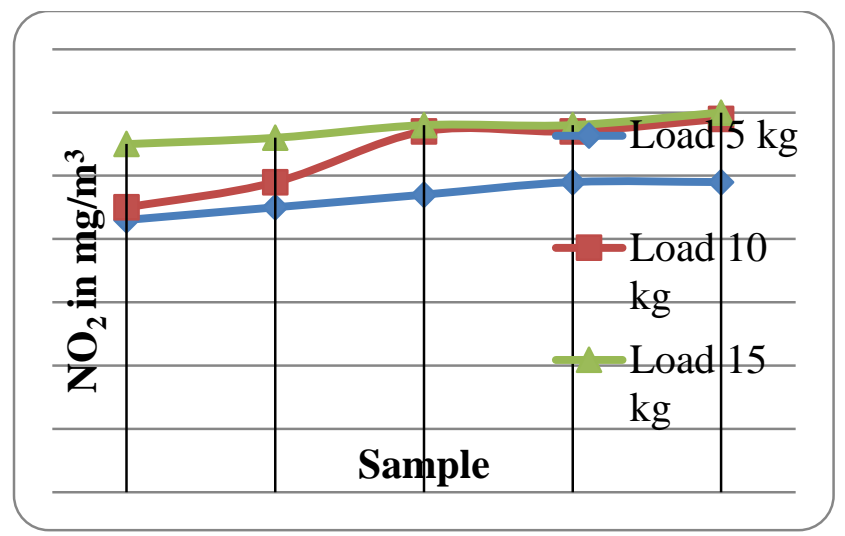

Figure 7: Change of $\mathrm{NO}_{2}$ with respect to load for different samples

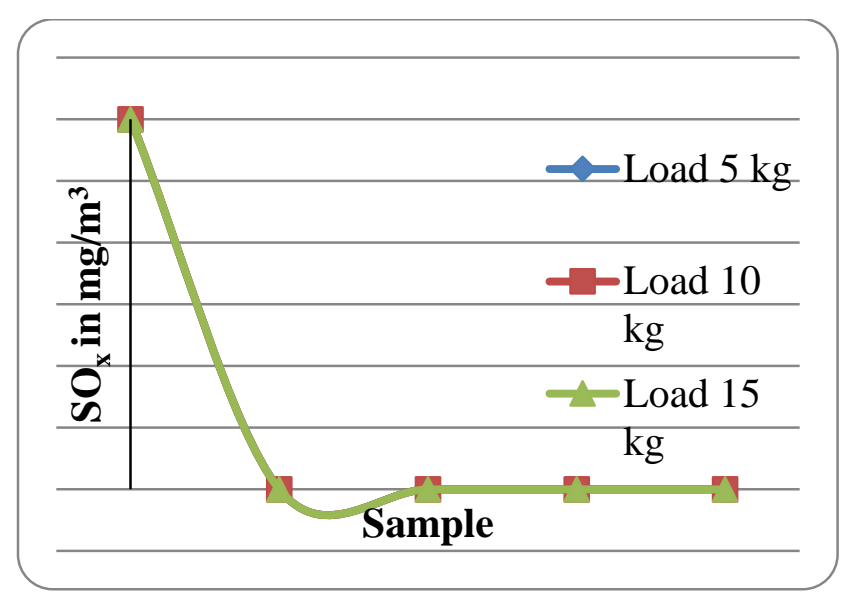

Figure 9: Change of $\mathrm{SO}_{\mathrm{x}}$ with respect to load for different samples

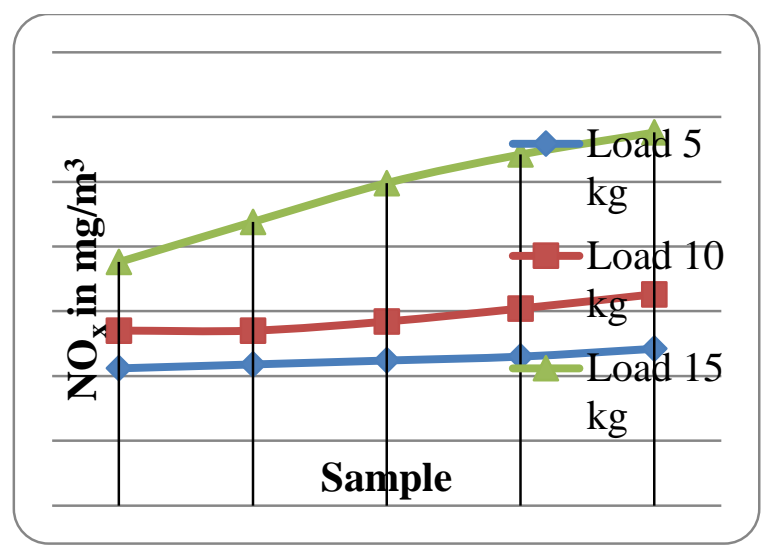

Figure 8: Change of $\mathrm{NO}_{\mathrm{x}}$ with respect to load for different samples

\subsection{Result and Discussion}

In figure 1 the change of $\mathrm{CO}$ with respect to load for different samples are decreasing as the content of biodiesel increases. That means the diesel give rich running engine and it becomes lean running at biodiesel fuel. It is noted that $\mathrm{CO}$ readings are indicator of a rich running engine. In fig. 2, 4, 5 it is seen that the values of the $\mathrm{CO}_{2}, \mathrm{NO}, \mathrm{NO}_{2}$, with respect to different load for different samples remains mostly equal, so it may conclude that the biodiesel and its samples can used directly to the compression ignition engine. In fig. 3 it is seen that the value of $\mathrm{HC}$ remain same for the sample B00 and B10 and then increases with increase the increase value of the biodiesel in diesel. The values of $\mathrm{NO}_{\mathrm{x}}$ remain almost same for different samples at lower load and at high load it increases with increase in value of biodiesel blending as shown in the fig. 6 . In fig. 7 it is observed that the blending of diesel and biodiesel gives nil value of the $\mathrm{SO}_{\mathrm{x}}$ for different sample at all loads. 


\section{References:}

1. Leung DYC et al Optimization of exhaust emissions of a diesel engine fuelled with biodiesel Energy \& Fuel 2006, 20, 1015-1023

2. Breda Kegl Experimental investigation of optimal timing of the diesel engine injection pump using biodiesel fuel Energy \& Fuel 2006, 20, 1460-1470

3. Zhang $\mathrm{Y}$ et al Impact of biodiesel on $\mathrm{NO}_{x}$ emission in a common rail direct injection diesel engine Energy \& Fuel 2007, 21, 2003-2012

4. Cheng CS, Cheng C, Chan TL, Lee SC, Yao C, Tsang KS Emission characteristics of a diesel engine fueled with biodiesel and fumigation methanol Energy \& Fuel 2008, 22, 906914

5. H. Rahman, A. G. Phadatare Diesel engine emissions and performance from blend of karanja methyl ester and diesel Biomass and Bio-energy 27 (2004) 393 - 397.

6. Kousonlidon M, Fontaras G, Leonidas N, Samaras Z Biodiesel blend effects on commonrail diesel combustion and emission Fuel 89, 2010, 3442-3449

7. Randzzo ML, Sodí JR Exhaust emission from a diesel powered vehicle fuelled by soybean biodiesel blends (B3-B20) with ethanol as an additive (B20E2-B20E5) Fuel 2011, 90, 98103

8. A S Ramadhas, S Jayaraj, C Muraleedharan Characterization and effect of using rubber seed oil as fuel in the compression ignition engine Renewable Energy 2005, 30, 795-803

9. Ozkan M Comparative study of the effect of biodiesel and diesel fuel on a compression ignition engine's performance, emissions and its cycle by cycle variation Energy \& Fuel, 2007, 21, 3627-3636

10. Kannan TK, Marappan R Study of performance and emission characteristics of a diesel engine using Thevetia peruviana biodiesel with diethyl ether blends European Journal of Scientific Research, ISSN 1450-216X, vol. 43, No. 4, (2010) pp 563-570

11. Biodiesel Standard, ASTM D6751, USA 2007

12. Biodiesel Standard, EN 14214, European Standard Organization, 2003

13. Rajput R. K. ATextbook of Internal Combustion Engines Laxmi Publications (P) Ltd, New Delh, Second Edition-2007, Reprint 2013

14. P. K. Nag Basic and Applied Thermodynamics The McGraw Hill Companies, New Delhi, Second Edition, 2010

15. Yunus A Çengel, Michael A Boles Thermodynamics An Engineering Approach The McGraw Hill Companies, New Delhi, Sixth Edition, Chapter 8, Pg. 423-483, 2010. 